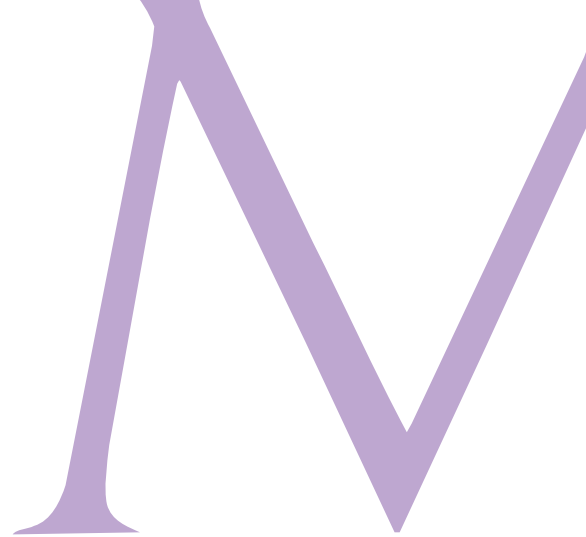

em humanos, na descrição do papel de cada autor ao final dos artigos, na divulgação de anexos com detalhamento de experimentos que não cabem no espaço reservado aos artigos, entre outros.

Multiplicam-se versōes multimídia de artigos científicos, a exemplo do projeto "O artigo do futuro" anunciado em 2009 pela editora holandesa Elsevier e colocado em prática pela revista Celle já disseminados em outras publicaçōes. O objetivo é que seja permitido não apenas a leitura horizontal, aos modos de um artigo impresso, mas que os gráficos, imagens, resultados, referências possam ser cruzados com outros artigos de modo a potencializar para uma leitura mais profunda do estudo, fazendo conexôes com outras pesquisas.

Um dos pontos centrais de debate éa busca por um processo de peer review mais transparente e eficaz. Isto porque ele não tem sido suficiente para diminuir os casos de má conduta acadêmica, dentre eles o número de retrataçôes cresce em ritmo superior à publicação de artigos, como mostraram R. Grant Steen, Arturo Casadevall e Ferric Fang, em artigo da Plos One de 2013 (DOI 10.1371).

Há ainda as questôes que envolvem o acesso ao conteúdo dos periódicos. As grandes editores internacionais costumam cobrar duas vezes: pela submissão dos artigos e pela leitura integral dos artigos. No Bra- sil, líder mundial em acesso aberto, os periódicos já começam a cobrar pelas submissōes e tentam fortalecer sua internacionalização e se manter gratuitos para o público leitor.

COMEMORAÇõES A partir de 6 de março, data de fundação do Philosophical Transactions, a Royal Society inicia uma série de eventos comemorativos, começando com uma exibição de vídeos sobre artigos seminais que inspiraram cientistas e transformaram o mundo. De 19 a 21 de março uma grande conferência em história da ciência ("Publish or perish? The past, present and future of the scientific journal") reúne especialistas de universidades britânicas, americanas e francesas para debater os desafios presentes e futuros das publicações científicas. De 20 a 21 de abril e de 5 a 6 de maio a instituição prepara mais debates acerca do "futuro da comunicação científica especializada com enfoque em temas polêmicos da comunicação científica, como o impacto da tecnologia, o surgimento da cultura científica e como cientistas devem se comunicar no futuro", como informa o site da Royal Society. Após mais de três séculos, estamos assistindo transformações que vão ecoar nos modos de produção de ciência dos próximos anos. Mais motivos para comemorarmos.

Germana Barata

\section{DIVULGAÇÃO CIENTÍFICA}

Parasitologia em quadrinhos aproxima ciência da população

Isabel Vincent é pesquisadora do Centro de Parasitologia Molecular Wellcome Trust (WTCMP, na sigla em inglês), no Reino Unido, onde estuda o protozoário Trypanossoma cruzy, que causa a doença de Chagas. Ela é mais conhecida, no entanto, como Izzy, personagem dos gibis publicados pelo Wellcome Trust para divulgar pesquisas e informações sobre doenças parasitárias negligenciadas como verminoses, doença do sono e leishmaniose. Ligado à Universidade de Glasgow, o centro dedica-se exclusivamente ao estudo dos impactos dessas doenças, ao desenvolvimento de medicamentos e de métodos de controle. A primeira revista em quadrinhos publicada pelo Wellcome Trust foi Parasites, em 2010. "Inicialmente foram impressas cinco mil revistas mas, com as reimpressões, chegamos a 10 mil exemplares", conta Alexandra Mackay, que gerencia o centro de pesquisa e coordena as ações de divulgação científica. "Escolhemos os quadrinhos porque pensamos que seria uma forma de comunicação divertida, que atingiria todas as 
